performance and of dimensions of components and equipment and on artificial lighting of buildings, particularly of shops, museums and art galleries, should be pressed forward, while other investigations should be instituted into minimum standards of quality in house design and construction, and standardization generally.

Among the American practices adoption of which is recommended are simplification of design of buildings for greater standardization and for mechanization of constructional work, greater use of factoryproduced units and assemblies, increased employ. ment of scientific workers for industrial research in the factory and in the field, encouragement of operatives by spreading information concerning the job and by official recognition of good eraftsmanship and greater use of plant machinery and hand-power tools. Finally, the report recommends that legislation be promoted with the object of securing registration of architects and of professional engineers, so that building plans shall be prepared by registered persons only.

\section{SUB-ANTARCTIC AND ANTARCTIC POLYZOA}

$\mathrm{D}^{\mathrm{n}}$ R. HASTINGS' extensive monograph on part of the Polyzoa of the Discovery collections includes much careful and critical work*. The six families involved are the Scrupocellariidæ, Epistomiidæ, Farciminariidæ, Bicellariellidæ, Aeteidæ and Sorupariidæ. The last family is, however, included with the Cellularina merely for convenience, and it is not intended to imply that it certainly belongs to that group.

The most important part of the work is undoubtedly the distributional data. Recent hydrological investigations made by the Discovery expedition have been available throughout, and correlation of the distribution of the antarctic and sub-antarctic species with the hydrology gives suggestive results. Thus change of hydrological conditions at the Antarctic Convergence appears to have a decisive influence on the non-abyssal Polyzoa. The presence of species with antaretic affinities in a zone off the Patagonian shelf is probably influenced by antarctic wa ers, and the distribution of abyssal species is possibly related to warm and cold deep currents.

An interesting fact is the similarity of the polyzoon fauna of Heard Island to that of the other islands in the South Indian Ocean although the hydrological conditions are different. Deacon (1933) has shown that these islands of the South Indian Ocean are hydrologically on the borderland between the Subantarctic and the Antarctic Convergence, Heard Island being well to the south and clearly antarctic hydrologically, but there appear to be grounds for regarding the Cellularine polyzoa of the islands, including Heard Island, as sub-antarctic rather than antarctic. It may be pointed out, however, that while Heard Island is connected with Kerguelen Island to the north by a submarine ridge, it is separated from the nearest point on the Antarctic main-

\footnotetext{
* Polyzoa (Bryozoa) I. Scrupocellariidae, Epistomilidae, Farcimin ariidae, Bicellariellidae, Aeteidae, Scrupariidae. By Anna B. Hastings. Discovery Reports. Vol. 22. Pp. 301-510, plates v-xiii. Issued by the Discovery Committee, Colonial Office, London, on behalf of bridge: At the University Press; 1943.) 9d. net.
}

land by some eight hundred miles of deep sea, for the so-called Kerguelen-Gaussberg ridge, although it represents a considerable rise in the floor of the great basin south of the Indian Ocean, still shows depths of more than a thousand fathoms over most of its length. The Patagonian region, on the other hand, has a series of stepping-stones with the Antarctic provided by the islands of the south antillean arc. In considering the distribution of a group such as Polyzoa, which are sessile during a large part of their life-history, these facts may help to explain why a correlation with hydrological conditions apparent in one region does not work in the other.

The collection is rich in ancestrulæ (the ancestrula being the first zooecium of the colony formed by the metamorphosis of the larva). These are different from the rest of the colony and important from a systematic point of view. They are only known in a small proportion of the species and much new material is deseribed here. It was thought that these might give evidence of the breeding seasons. Although only tentative, the facts assembled seem to show that the ancestrulæ are more frequently found in the early months of the year, although colonies were collected over a period of from four to seven months.

The report is very well illustrated both by numerous clear text figures and photographic plates.

\section{THE GEOLOGY OF RHUM (INNER HEBRIDES)}

$A^{T}$

$T$ the meeting of the Geological Society on January 19, Dr. E. B. Bailey presented some new facts and a revised interpretation of the igneous and tectonic geology of Rhum. A great dislocation described by Harker in 1903 as a Palæozoic thrust is now claimed as a Tertiary ring-fault with central uplift. Harker was intluenced by the curvature of the outerop of the fault, and by the slump-bedding of the Torridonian which he interpreted as a tectonic structure. He was also misled by a patch of Trias which he mistook for crushed Torridonian; by certain associated banded Lewisian gneisses which he regarded as banded Tertiary igneous rocks ; and by a set of Tertiary explosion-breccias which he thought were crush-breccias developed by early Palæozoic thrusting. Bailey considers the outstanding tectonie feature of Rhum to be a block uplift, amounting locally to about 7,000 ft., which took place at the start of the Tertiary vulcanicity and was indirectly responsible for the inter-lava river gravels of the neighbouring island of Canna. The peridotites of Rhum were later than the block uplift; they rose along ring-fissures about a centre well to the west of that surrounded by the great initial ring-fault.

At the same meeting S. I. Tomkeieff described the petrology of the famous ultrabasic and basic plutonic rocks of the Island. The mineral compositions of the rocks and the order of crystallization have been accurately determined and it is shown that tho ultrabasic rocks comprise a continuous peridotite-allivalite series which is assumed to have been formed by the crystallization of an already differentiated hetero geneous magma. How this differentiation took place remains the outstanding problem still to be solved. The basic rocks are mostly olivine-eucrites, locally strongly banded. A later boss of granophyre is found to be contaminated along its junction with the eucrite. 